The Impact of Contextual Fragility on Development in Practice: Perspectives from Zimbabwe

\begin{abstract}
This article explores the impact of contextual fragility on development in practice in the context of partnership working. The utilization of oppressive legislation and stringent registration for CSOs by a state fearful of losing political hegemony resulted in limited community participation and $\mathrm{CBO}$ reluctance to engage in advocacy activities deemed political despite northern partner eagerness. Financial distress led to a partnership termination, partial and non-implementation of some development activities. Utilizing contextual analysis to unmask the heterogeneous nature of fragile contexts can be a valuable starting point in capturing unique complexities and irregularities in each context to inform program planning.
\end{abstract}

Key words: Civil Society; Participation; Partnerships; HIV/AIDS; NGOs; Sub Saharan Africa

\title{
Introduction
}

There is an increasing recognition that an enabling environment for civil society organisations (CSOs) such as non-governmental organisations (NGOs) and community- based organisations (CBOs) is vital for sustainable development. However, despite this recognition, some governments embrace CSOs at international level while restricting their operations at national levels for fear of losing political hegemony (Hayman et al. 2013). While state role in development remains a subject of ideological debate, there is consensus it needs to be competent in delivering its core functions which Kingsbury (2014) identifies as: equal and consistent application of the law, impartial judiciary - police and defence force; levying taxation; overseeing infrastructure including transport and communications; the delivery of education and some degree of health care. Hence, state capacity to deliver these functions, and making use of aid to effectively sustain development, have been identified as key development (Fukuyama 2004). States at the bottom end of functionality are characterised by state failure or fragility (Kingsbury 2014) and are more dependent on aid often channelled via CSOs due to state - donor distrust. However, CSOs are not immune to the implications of operating in such contexts. Whatever the implications maybe, they are context dependent. This suggests labelling states failed or fragile based on a standardized 


\section{Cathrine Madziva}

framework potentially limits attempts to understand how each context impacts on development in practice.

While there is consensus that state fragility is, multidimensional and underlined by numerous causes (Mcloughlin 2012), the discourse has been accused of failing to pay sufficient attention to the analysis of "... unique contextual factors in both fragile state development literature and practice" (Ware 2014: 13). This is despite theoretical acceptance of such factors being important to development work. For example, the OECD principle 1 of Principles of for Good International Engagement for in Fragile States and Situations calls for sensitivity to context. Notably, appropriate consideration of unique contextual factors is a prerequisite for understanding how specific fragile contexts impact on development in practice which is crucial in informing future practice. While a broad programme of research which considers contextualized investigations is required, this paper aims to make a contribution to our understanding of how contextual fragility impacts on development in practice through an INGO - CBO partnership case study supporting vulnerable children. It does so by exploring the experiences and perspectives of development actors in the partnership among other collaborations in Zimbabwe, a country which has repeatedly identified as a fragile and failed state (Makuwira 2014; Brown and Stewart 2009; Fund for Peace 2017).

\section{Background: Civil Society - State relations in Zimbabwe}

The Rhodesian colonial government (1890 - 1980), now Zimbabwe, adopted segregationist policies towards the black majority, which denied them rights to participate in democratic institutions (Moyo 1993). After independence, the state encouraged formation of CSOs driven by a desire to build national unity (Moyo 2000). These mobilized around social services while those from the early 1990s onwards began focusing on human rights and governance, HIV/AIDs and gender, black empowerment and environmental concerns (Raftopoulos 2000). This coincided with the introduction of neo liberal policies (Macdonald 2000) which left the poor increasingly reliant on CSOs for social services. Against a backdrop of state encouragement of CSOs formation, Moyo (1993) argues that organisations formed during this period suffered from lack of political space and dependency on state tutelage, which curtailed self-determination. While the lack of pluralism resulted in the formation of organisations only focusing on their immediate concerns, the armed struggle leading to independence

"produced a violent culture of intimidation and fear within ranks of the liberation movement themselves and among their social base of peasant supporters...this 
created an environment of death, terror and fear ... to the utter misery of peasants who had to contend with equally brutal colonial forces. This resulted in a culture of fear in which violence was perpetrated in the name of nationalism and socialism... this has continued after independence with the same consequence. This is why peasants are conspicuously afraid of ZANU PF, particularly during elections: the campaign tactics of the ruling party are based on intimidation and death threats" (Moyo 1993: 12)

These assertions tally with 2008 and 2013 election events whereby opposition party supporters in some rural communities experienced state sponsored violence (Amnesty International 2013). The 2008 election dispute resulted in a coalition government between Zimbabwe African National Union Patriotic Front (ZANU PF) and the Movement for Democratic Change (MDC). However, due to the coalition's fragile nature, this provided no respite for long persecuted CSOs which the opposition relied on for technical expertise (International Centre for Not-for-Profit Law [ICNL] 2017).

Since winning 2013 elections by a majority, ZANU PF has been preceding over a crippling socio economic and political crisis. This has instigated the rise of less structured social movements organised via social media. While civil society actors are increasingly vocal in their demands for state accountability, ZANU PF has responded by a nationwide crackdown, including unleashing threats, violence and arrests (ICNL 2017). As of November 2017, the ruling party adopted a conciliatory tone towards the opposition after an army intervention supported by protestors from all political divides culminated in the ousting of President Robert Mugabe. Currently at the helm is the former vice president, Emmerson Mnangagwa and whether his conciliatory tone translates to real change on the ground remains to be seen particularly with regards to forth-coming general elections in July 2018.

\section{The Legislative Environment}

A fact-finding mission to Zimbabwe by African Commission on Human Rights (ACHPR) in 2002 highlighted the revival of old laws utilized by the colonial state to control and limit civil liberties e.g. Public Order and Security Act, (POSA) 2002 and the Private Voluntary Organizations Act (PVO). Section 5 of the POSA makes it an offence to establish an organisation to overthrow the government by unconstitutional means, usurp its functions or coerce it through physical force, boycotts and civil disobedience. The PVO act, which governs CSOs existence and operations dates back to 1967 and was enacted in 1995 for NGO registration almost in its original version (International Bar Association [IBA] 2004). Registration became mandatory in 2002 with penalties such as fines and imprisonment for carrying out activities or soliciting funds without registration (ICNL 2017). Under the 


\section{Cathrine Madziva}

auspices of 'public interest' as stipulated in section 21, the overseeing minister has power, subject to own discretion, to deregister any CSO (Raftopolous 2000). As Michael (2004) argues, 'Public interest' can be used by the state to legitimize its own interests. Further concerns for CSOs came in 2004 as the state sought to introduce a NGO Bill, a stringent possible successor to the PVO act which sought to prohibit registration of foreign NGOs focusing governance and local CSOs receiving foreign funding for governance issues (IBA 2004). The implications of this would have been severe given that in development aid, good governance is viewed as crucial for poverty eradication (World Bank 2002). Against a backdrop of protests, the bill was abruptly shelved.

\section{Theoretical framework: Fragile state}

While the concept fragile state is subject to debate, Stewart and Brown (2009: 7) categorise state fragility into three dimensions:

- Authority failures where the state lacks the authority to protect its citizens from violence including organised political violence

- Service failures where the state fails to ensure that all citizens have access to basic services such as health, basic education inter alia

- Legitimacy failures where the state lacks legitimacy in majority of citizen's eyes as partly evidenced by suppression of the opposition, absence of civil and political liberties and media control.

Beyond a fragile state lies a failed state described as one, which has regressed further into failure to provide political goods and impose order resulting in total breakdown of political order and systems of governance (Rotberg 2003). This entails international risk and complete failure to provide basic needs for citizens. Though Zimbabwe was identified as a failed state or bordering state failure between 2006 - 2008 (Muvingi 2008) as Makuwira (2014) argues, some governance structures remained in place. Hence, far from authority breakdown to maintain order, there was a government albeit a very authoritarian one. This raises questions regarding labelling Zimbabwe a failed state. Crucially, this suggests labels can mask the reality that states can fail in some aspects while still being functional (Mcloughlin 2012).

Stewart and Brown's (2009) categorization of a fragile state however closely fits with Zimbabwe's situation. In relation to authority failures, there is evidence of state sponsored human rights violations and political intimidation (Amnesty international 2013) with the police labelled the worst perpetrator of violence against citizens at the behest of the ruling 


\section{Cathrine Madziva}

party (Mavhinga 2016). As Mavhinga notes, this has been accompanied by presidential threats at the judiciary for upholding citizens' right to protest which sought to undermine its independence. In terms of services failure, there has been a drastic deterioration in health services, sanitation and water (Fournier and Whittall 2009) and education. Legitimacy failures have been glaring as evidenced by mass protests against the state with political activists bearing state violence brunt (Zimbabwe Peace Project 2015). Furthermore, some protests were banned which violated citizens' rights to peaceful assembly and freedom of expression enshrined in Zimbabwe's constitution (Mavhinga 2016).

While to some extent, this supports Zimbabwe's categorization as a fragile state, solely situating this study in this framework potentially masks the heterogeneous nature of fragile contexts. This consequently limits our understanding of how contextualized fragility impacts on development in practice, hence the need to consider Zimbabwe's additional unique contextual factors discussed below.

There is ample evidence that the introduction of economic structural adjustment programmes from 1992 onwards had disastrous social outcomes thereby turning one of Africa's best health care and education system into shambles (Macdonald 2000). Thereafter, the chaotic violent land reform program resulted in low farming productivity and plummeting foreign currency flows as farms landed in the hands of ill equipped ZANU PF elites (The Economist 2016) just as the HIV/AIDs epidemic imploded (UNAIDS 2016). This, exacerbated by droughts in the region reduced Zimbabwe to a food aid case.

Partly due to irrational monetary policies, the period before the coalition government witnessed the highest hyperinflation in the $21^{\text {st }}$ at 80 billion, (The Economist 2016) but the adoption of multiple currencies i.e. mainly the South African rand and US\$ temporarily stabilised the economy. However, since 2013, ZANU PF has been presiding over a weak economy dogged by rampant corruption, mass unemployment, a cash crisis which culminated in the introduction of much criticized bond notes (The Economist 2017). By considering these additional unique contextual factors, this paper aims to present a more nuanced discussion on how contextualized fragility impacts on development in practice.

\section{Study Context and Case Selection}

This study was conducted in rural Manicaland, Zimbabwe. While the larger study explored, partnership working between INGO Y - CBO X in supporting vulnerable children (Madziva 2017), this paper focuses on the impact of a fragile context on development in practice as 


\section{Cathrine Madziva}

one of the themes. At the time of study commencement in 2006, Zimbabwe was going through a major socio-political and economic crisis, albeit still on going.

The selection of the original case study selection was based on a desk top research process of eliminating urban-based development partnerships between INGOs and CBOs focusing on vulnerable children affected by HIV/AIDS using the Directory of Development Organisations operating in Zimbabwe. At that time, the INGO Y and CBO X partnership was the only one identified in rural Zimbabwe.

\section{Methods and study participants}

Research participants were recruited to participate via purposive sampling as this enabled engaging those possessing knowledge and experience of doing development work in the fragile context on the back of the partnership case study. Individual in-depth interviews were utilised for data collection and documentary analysis, which entails studying of existing documents (Hammersley and Atkison 1995) was utilised to further understand and illuminate on the impact of contextual fragility. Documents analysed in this regard include; Annual Reports, Records of Proceedings Annual Review Workshop Reports and Policy Documents, Research Papers and Evaluation Reports.

Study participants on this theme included 2 INGO staff; 2 key informants (development consultants) and 6 CBO Staff with a combined average of 10 years' experience of working in development in Zimbabwe. All participants held degree and or postgraduate level qualifications with an age range of $31-55$ years old.

The study received approval from London Metropolitan University Research Ethics Review Committee. Informed and written consent were obtained from all participants. Participants were anonymised by using alphabetic letters to ensure confidentiality while retaining organisational link. Given topic sensitivity, the organisations have been anonymised.

\section{Data Transcription and Analysis}

Each in-depth interview was held in English and lasted an average of 50 minutes. Interviews were digitally recorded and transferred as audio files to a computer before transcription. Thematic Framework, a method of data analysis which involves organising data by emerging themes (Ritchie et al., 2004) was used for data analysis. The researcher began by indexing the data, which involved using labels that are semantically close to the terms being represented. The index was manually applied by inserting references in the margins of 


\section{Cathrine Madziva}

scripts wherever a relevant theme was identified across the entire data set to enable cross analysis. Thereafter, data were sorted by themes via thematic charts.

\section{Findings}

This section presents study findings based on emerging themes as follows: an oppressive CSOs legislative framework; work permit challenges, financial distress; advocacy and lobbying challenges.

\section{An Oppressive CSOs Legislative Framework}

Findings indicate that the legislative environment was perceived extremely challenging for INGO $Y$ and CBO X, as well as other CSOs in the country. Though never signed into law, the NGO bill caused uncertainty as noted:

"It [NGO Bill] actually sent a lot of international donor agencies scurrying for cover; a lot of international donors and INGOs relocated to Botswana, South Africa, Zambia in time to escape the bill; they really thought that it was going to be signed but it worked, the result is that a lot of CBOs, NGOs collapsed" (KI P)

"It [bill] made us feel vulnerable as a foreign INGO. Some pulled out around that time because of uncertainty, we had a neighbour here, they were from Sweden and they relocated to Zambia" (SC - INGO Y)

As explained above, the bill led to the collapse of local CSOs due to less funding availability as some donors and INGOs relocated. While INGO Y continued working in Zimbabwe, it felt vulnerable given its political approach to poverty eradication:

"If INGO $Y$ were to register under the NGO bill, INGO $Y$ would present current activities ... highlight that their concern was to fight structural causes of poverty which is how the organisation works. This is criminal according to the provisions of the bill. INGO $Y$ is interested in addressing the structural or root causes of poverty and not just address the symptoms" (Record of Proceedings of the INGO Y Zimbabwe Annual Meeting, 2005: 13).

As INGO Y weighed the bill's implications, $\mathrm{CBO} X$ felt challenged as remaining weary donors committed to short term funding as explained:

"The situation is not conducive, anytime they [donors and INGOS] can be affected by the NGO bill. They say no to longer-term grants because suppose the government actually comes in and closes the whole show. This is a big problem for us because we can't plan ahead" (SA - CBO X).

As noted, short term funding had negative implications for projects planning. In line with this, the restrictiveness of POSA and the police force's failure to respect citizens' rights emerged problematic: 
"This POSA still controls the meeting of people, the police are not respecting the rights of citizens, the right to demonstrate, express opinions, the right to meet even if its non-political meetings. Someone always wants to see what you are meeting to discuss about ... the environment is not very open and this place is very restrictive" (SC - INGO Y)

As explained above, a restrictive environment limited community mobilization with negative implications for participation. After the bill was shelved, evidence suggests the environment remained hostile:

"Even in the absence of the NGO bill, district and provisional authorities have sought to control and monitor the activities of NGOs ... this has resulted in the deterioration of relations between government and NGOs".

(INGO Y Annual Report 2005: 9)

In line with the oppressive legislative framework, findings suggest it took $\mathrm{CBO} X$ years to obtain government registration which was perceived extremely challenging as noted below:

"It was a long struggle, it took us over 5 years to get registered with the government, and yet when looking for funders, they will say, are you a registered $C B O$, if you are not registered then we cannot become partners... you are moved from one office to another, it's as if the government doesn't want you [CBO] to be registered" (SA CBO X)

This left the $\mathrm{CBO}$ in a challenging situation as some funders wouldn't work with unregistered organizations, even though registration wasn't yet mandatory.

\section{Work Permit Challenges for Expatriate Staff}

Findings indicate that INGO $Y$ contended with immigration challenges pertaining to its international staff as highlighted below:

"INGO Y was generally concerned with the negative changes in the operating environment ... the deportation orders served on key INGO Y staff, i.e. the previous country director and administrator, the difficulties of securing work-permits for remaining and new staff" (Record of Proceedings of the INGO Y - Zimbabwe Annual Meeting 2005: 13).

The deportation of key country programme workers posed challenges for programmes' continuity for INGO Y and partners.

\section{Financial Distress}

Findings suggest that $\mathrm{CBO} X$ lost money intended for development activities due to bank closures at the height of the economic crisis. In response, the partner, Donor $\mathrm{V}$ abruptly terminated the partnership as explained below: 
"We went into partnership with Donor $V$, I think we operated with them for two years and they came here for an audit. That time, some of the banks here closed and some of the monies we had banked had come from Donor $V$, it disappeared. We couldn't retrieve it, we even went to see Gono [then Governor of the Central Bank], and we have never been able to get it back. We went to solicitors, we went to see the big people to say this money is for our programmes in the community, for orphans and vulnerable children but nothing happened. We have more than 100 million [then between US\$ 5000 - \$10000] owed to us. We wrote to our partner (Donor V) to say this is what has happened, it's beyond our control, we can't retrieve our money and the bank has been closed. They said you have broken the partnership agreement, these people they are now based in Zambia, that is one example of a donor who moved out of this country to another because of the NGO bill, they didn't really support us, they cut their support" (SA - CBO X).

While Donor $V$ was not interviewed for this study, this incident spelt the end of the partnership though the money's disappearance was beyond CBO X's control. Crucially, it deprived children of intended support such as school fees and food. Donors were also accused of not fully understanding the context and poor commitment as the participant further put in this way:

"Our partners in the North don't have a broader picture of things happening here. I gave you that example of the bank closing with our monies but the donor didn't understand it. Partners in the north don't really comprehend the atmosphere here especially after the NGO bill. This environment is extremely challenging to work in and partners in the north need to understand this a bit more, their commitment to us in such challenging times is like today we are together and tomorrow we are not" (SA-CBOX).

In line with this, hyperinflation posed programme-planning challenges as CBO staff put it this way:

"Prices are not stagnant, they are always going up because of inflation which makes it difficult to do programming, we are constantly revising this, it makes planning difficult" (SB - CBO X).

While INGO Y was flexible to review budgets, evidence shows some donors stuck to the original budgets leaving some activities incomplete:

"Most of the intended activities were partially done because of increased costs and no funds were available to match the inflated budget. This is because donors require an annual budget and do not consider inflation to review budgets. This had a chain reaction as also schools increased their fees when $C B O X$ had already paid giving it a deficit" (CBO X Participatory Review Workshop Report 2003:5).

The official pegging of the Zimbabwean dollar against major currencies had major implications for development programs as the currency was overvalued resulting in the 


\section{Cathrine Madziva}

emergence of a black market reflective of the actual supply and demand. INGO Y staff put it this way:

"They [local partners] would benefit more but now it [currency] is controlled. US\$30 000 is a different amount in a controlled regime than in a liberalised regime. You can see the gap between the exchange rate of $\$ 1000$ [open market/black market] and the official rate of $\$ 250$. Those resources could benefit the communities, that one is a key problem, economic crisis, it's a major problem" (SC- INGO Y).

This suggests that while development programmes lost out state coffers gained. While the same amount of money was of little value in Zimbabwe, in other countries it went a long way as explained below:

"US\$20 000 a year may not be enough but then we have some partners in Zambia, Mozambique getting the same amount of money and they are doing very well" (SD INGO Y).

Linked to economic crisis was the deterioration of public transport and lack of fuel which impacted negatively on development activities:

"The deterioration of public transport and general shortage of fuel in the country has made it difficult for communities particularly in rural areas to interact regularly and effectively. It has been difficult for NGOs in general and some INGO partners to reach out to communities" (INGO Y, Annual Report 2005: 10).

\section{Advocacy and Lobbying Challenges}

Findings showed the need to engage in advocacy created tensions between $\mathrm{CBO} X$ and funding partners. $\mathrm{CBO} X$ staff bemoaned pressure from partners, as one put it this way:

"INGOs and donors like to ask; what have you [CBO] done to fight for democracy? Like Donor $W$, they are very fond of all those things, but how do you do it, if your board says we cannot be involved in these things? Once you [CBO] come out in the open like that then people will say you are doing politics, but that isn't the concept of the $C B O X . C B O X$ are people who have problems that are social problems that are affecting them, and they want to deal with those problems and nothing else" (SACBOX).

The management board alluded above is the СВO governing structure made up of community members. Hence, the refusal of this board to engage in political related activities meant no implementation. However, the quest to deal with nothing else other than the immediate social problems evidenced short sightedness regarding the role of a political approach in tackling root causes of poverty. Staff appeared to share the board's viewpoint as one put it this way:

"For the partner, you get as a donor, they will say, you have to comply to being proactive, to argue for democracy, advocating for human rights and so on. But, you know once you get yourself in such a situation, you are getting yourself in the political arena, then you are seen as CBO $X$ arguing for advocacy, pressuring the 
government to change certain things and then the government questions; are they a political group now?" (SB - CBO X).

While pressure from donors was evident, there appeared a deep-rooted fear of being perceived as a political entity by the state. However, INGO Y was aware of the challenges faced by its partners as noted:

"Some communities are no go areas, depending on the politicians that are there. They are some crazy politicians who are suspicious of NGOs going into Human rights issues. They are suspicious about [NGOs] going into governance issues, it is like for them, you have no business to do civic education, to do governance" (SC - INGO Y).

As suggested above, some politicians acted as gate keepers which made it impossible to engage communities. This made it challenging for INGO $Y$ given its poverty eradication mission is grounded in a political approach which entails:

"... creating political space for the activities of the poor; strengthening and building capacity in CSOs for political activities; engaging in issue - based advocacy and lobbying; providing linkages from the local to the national and international levels; building alliances between different actors in civil society; getting involved in broader social movements and providing links to the emerging global civil society" (INGO Y 2005: 7-8).

However, the parameters of this political approach were clearly spelt out as:

"[Not getting] involved in any way in party politics in the programme countries... [there is a recognition] poverty can be reduced by concrete interventions of a service delivery nature... the impact of these is limited, hence must be linked to advocacy in order to produce a greater impact" (INGO Y 2005: 8).

As explained, this does not relate to party politics. Faced with advocacy pressures, $\mathrm{CBO} X$ took cover under the National Association of Non-Governmental Organizations (NANGO):

"For us [CBO X] to really make good relations with donors, we normally tell them we fight for democracy through our networks like NANGO, but they want to see you doing it, there on the forefront of it, that is where we don't agree" (SA - CBO X).

However, a local development consultant argued:

"NANGO is a necessary nuisance because it is an umbrella body for NGOs, [but] it does absolutely nothing; it is really a convenience so that civil society should not look so stupid. Basically, NANGO really is one of the most useless organizations ever, it is not effective, it's closer to the government than its members!" (KI P).

Documentary evidence echoes similar sentiments by a Zimbabwean human rights lawyer and activist:

"What mandate has NANGO to represent the NGOs? NANGO has only 250 members and in greater Harare alone, there are 1500 organisations!" (INGO Y- Zimbabwe Annual Meeting 2003:9). 


\section{Cathrine Madziva}

Given these criticisms, the legitimacy and effectiveness of the umbrella body was questionable. This raised concerns regarding its ability to engage in advocacy on behalf of members.

\section{Discussion}

\section{Oppressive Legislative Framework Implications}

This section discusses the implications of oppressive legislation on development in practice as follows: donor withdrawal leading to funding reduction and unpredictability; over extending legislation application by the police; stringent registration. While the NGO bill was never signed into law, it caused havoc as some donors abandoned ship believing its legal status imminent, against a background of repressive laws such as the PVO act and POSA being enforced. As donors relocated to neighboring countries, this translated to less funds on the ground (USAID 2008) leading to the collapse of some CSOs. Remaining donors moved from long term funding to short term. This impacted negatively on $\mathrm{CBO} X$ as it could not make long terms plans which threatened the continuity of some programs. As CBO X contended with funding challenges, INGO Y felt under immense threat due to its political approach to poverty eradication which it was prepared to defend.

As ICNL (2016: 2) argue, to carry out their work appropriately, CSOs require, "the freedom to exercise three independent rights: the rights to peacefully assemble, freely associate and openly expressive themselves". Findings suggest that on the back of POSA, the police denied some communities the right to peaceful assembly, even when agendas were none political. This limited participation which is crucial for sustainable development (Madziva 2017). While international CSOs are often accused of paying lip service to participation due to its costly nature (Harris 2008), these findings indicate that oppressive legislation can restrict participation. Hence, participation is not entirely dependent on international CSOs' willingness to resource, but equally requires an enabling legislative environment.

State use of restrictive legislative frameworks has been identified in countries such as Ethiopia, Eretria, Tanzania, Kenya, Egypt (ICNL 2016; Michael 2004). While some of these countries are not labelled fragile states, the World Bank (1997) notes that many African states use NGO legislation to restrict the sanctioned activities of CSOs from the political realm. Arguably, Africa is home to many fragile states (Fund for Peace 2017) and protecting political hegemony through oppressive legislation appears a shared characteristic between fragile and some none fragile states. However, due to authority and legitimacy failures, it 


\section{Cathrine Madziva}

can be argued that fragile states are more likely to utilize oppressive legislation to maintain the status quo. As Kagoro (2005) argues, given Zimbabwe's pre -independence history whereby CSOs tended to transform to political entities, state desire to thwart them isn't surprising. After the bill was shelved, findings show that the relationship between the state and $\mathrm{CSO}$ remained contentious with the former continuing to threaten CSOs existence which created uncertainty. For instance, before 2013 elections, the government accused 29 NGOs of engaging in political activities and suspended them leading to HIV/AIDS care and food distribution services being delayed with some being indefinitely suspended (ICNL 2016).

After CSOs registration became mandatory in 2002, 6 years after CBO X formation, findings indicate it took the $\mathrm{CBO}$ over 5 years to obtain this. The process was claimed arduous as though intended to discourage registration, which agrees with findings by Nassli (2014) in the case of Uganda. On this note, ICNL (2016: 3) argues:

"State authorities can exploit their decision-making powers to delay registration or renewal applications indefinitely or to arbitrarily interpret the law, strictly enforcing and harshly interpreting the smallest details against organizations deemed undesirable".

Writing about NGOs in Africa, Michael (2004) notes that African governments tend to curb CSOs power by exerting undue control on registration which is closely intertwined with the use of oppressive legislation to keep CSOs from engaging with political activities connected to their development agendas. Eritrean, one of the poorest and most fragile states is known to have introduced extremely stringent registration requirements which forced most INGOs to leave the country in 2011 (ICNL 2016). Hayman et al. (2014) attributes this to contexts lacking state-citizen accountability which is particularly the case with fragile states. Moreover, registration challenges potentially mitigate against the implementation of development projects given donors' reluctance to work with unregistered organizations. The need for caution is understandable given the case of 'briefcase NGOs', a wide spread phenomenon in Sub Saharan Africa albeit rare in Zimbabwe (Michael 2004). However, where registration is not mandatory, donors and INGOs seeking potential partners in fragile contexts should be flexible as some states use their power to control and purposively frustrate the process. 


\section{Cathrine Madziva}

\section{Work permit challenges}

This section discusses the implications of work permit challenges on development activities. In line with the hostile legislative framework, findings showed that INGO T expatriate staff faced challenges with obtaining and renewing work permits with some receiving deportation orders. This posed continuation challenges for some development programs while exacerbating the atmosphere of uncertainty. Evidence indicates that Médecins Sans Frontières, experienced difficulties in securing and renewing work permits for staff to respond to the 2008 - 2009 Zimbabwe cholera outbreak despite the acute shortage of medical professionals (Fournier and Whittall 2009). Another INGO, Catholic Relief Services was forced to leave Eretria due to similar challenges (ICNL 2016). This shows that states can be obstructive at the expense of citizens in dire need. Given that at the time this study was conducted, INGO T had been in Zimbabwe for over 20 years, much of that a period of relative state stability without similar challenges, it can be postulated that state fragility contributed to these work permit challenges. Worth reiterating is that the NGO bill sought to protect state political hegemony by prohibiting the registration of INGOs focusing on governance issues, a key focus of INGO T. Hence, work permits denials and restrictions may have been a strategy to weaken INGO T before the proposed legislation came into force.

\section{Financial Distress implications}

This section discusses the impact of hyperinflation, bank closures, overvalued pegged currency and the introduction of bond notes on development activities. The case of СBO $\mathrm{X}$ and Donor $\mathrm{V}$ shows that state failure to implement sound monetary and fiscal policy impacted negatively development in practice. The disappearance of CBO X's money in a bank closure spelt the partnership's end. Crucially, this led to development activities for children not being implemented as intended. The response of Donor $V$ to terminate the partnership on the pretext of a broken partnership agreement raises questions regarding donors' ability to appreciate risks associated with operating in fragile contexts. However, the case of Zimbabwe is not unique given past northern financial crisis. For instance, the 20072008 financial crisis showed that even long standing financial institutions can face a meltdown due to state failure to adequately regulate and monitor financial services (Soros 2008). The difference is that some northern financial systems, offer a measure of protection to customers in the event of financial mishaps, unlike in Zimbabwe where $\mathrm{CBO} X$ could not get anything back. This calls for extra scrutiny when banking in heterogeneous fragile contexts where financial systems may be unsound. For this reason, conducting contextual 


\section{Cathrine Madziva}

analysis may avail funding partners with in-depth understanding of contextual complexities and irregularities requiring extra consideration at planning levels as opposed to situational analysis as used by most CSOs (Foster 2002).

Findings also showed development programs lost money due to the overvalued pegged currency, as organisations were forced to exchange donor dollars through official channels while the black-market rate was 3 times over the official exchange rate. On this note, it can be argued that to some extent, state coffers gained while activities intended for the poor lost out. In the same vein, the introduction of bond notes has been viewed as an attempt to introduce a valueless local currency thereby making US\$ secured by CSOs only accessible to the Central Bank (ICNL 2017).

Hyperinflation made program planning extremely difficult resulting in most intended program activities facing partial implementation as donors would not revise budgets to cater for shortfalls, e.g. school fees for children not being fully paid leaving the CBO in debt. In the same vein, the acute public transport and fuel shortage which led to a nationwide near paralysis (The Economist 2005) compromised some development activities, particularly in rural areas due to limited interactions among communities who mostly depend on face to face communication due to the digital divide. This also made it difficult for INGO Y's partners, as well as other CSOs in the country to reach out to communities.

Currently, the country faces a cash crisis with imposed cash withdrawal limitations and the loathed bond notes have fuelled a black market with the U\$S facing extinction on the open market (The Economist 2017). As ICNL (2017) note, cash withdrawal limitations have severely curtailed CSOs' access to funds with negative program implications. While the financial crisis in Zimbabwe highlights state role in implementing appropriate monetary policy, it also underscores the need to sufficiently consider unique contextual factors so as to understand how specific fragile contexts impact on development in practice, the key argument advanced in this paper. Of all the countries classified as fragile states, none experienced Zimbabwe's hyperinflation rated the highest in the $21^{\text {st }}$ century at 80 billion (The Economist 2016). Hence, while there are probable similarities in fragile contexts, some underlying factors remain unique to specific contexts.

\section{Advocacy and Lobbying Challenges}

This section discusses advocacy and lobbying challenges alongside considering how these challenges potentially impact on the work of global policy advocacy networks. Findings showed $\mathrm{CBO} X$ viewed advocacy an undesirable engagement in politics beyond its social 


\section{Cathrine Madziva}

provision remit which concurs with findings by Michael (2004) among other local organizations in Zimbabwe and Tanzania. Fear of being deemed political with threats of deregistration by the state underpinned this position. Given the proposed NGO bill sought to thwart CSOs from the political realm and state intimidation, $\mathrm{CBO}$ X's reluctance was hardly surprising. Furthermore, this reluctance must be viewed in the context of Zimbabwe's colonial and post-independence history which Moyo (1993) credits with inflicting mass violence among rural communities. Thus despite signing a partnership agreement with INGO T with an advocacy component and receiving relevant training (Madziva 2017), CBO X's narrow social services focus tallies with Moyo's assertion that CSOs formed in Zimbabwe's rural contexts have no interests beyond their immediate concerns. This position put $\mathrm{CBO} X$ at odds with INGO Y's political approach to poverty eradication, as well as other donors. While it can be postulated that INGO T may not have been thorough with its partner selection process in terms of the political approach to poverty eradication as a shared partnership objective, by virtue of focusing on child rights as one of its key mandates, CBO $X$ 's reluctance to engage in advocacy was paradoxical. However, it's noteworthy that it did not completely shy away from advocacy as it engaged local communities around child rights related issues (Madziva, 2017). This appears to indicate service oriented CBOs can willingly engage in certain types of advocacy, with a red line drawn for activities deemed political because of state fear. For instance, seeking state accountability in relation to the realization of child rights may be deemed political in comparison to raising awareness of child rights among local communities. As findings indicate, human rights and governance issues attracted pronounced hostility from local politicians who acted as gate keepers, hence the CBO relegated this to its umbrella body. This agrees with findings by Safaids (2012), ICNL (2017) and Michael (2004) where CSOs seeking state accountability and human rights issues faced state harassment, arrests and in some cases torture which reinforces the idea of a state fearful of losing political hegemony. As Michael (2004), points out in the case of Zimbabwe and Tanzania, the latter though not identified as fragile, state fear has increasingly led to limited political space for $\mathrm{CSOs}^{\prime}$ engagement in advocacy and lobbying. Against this backdrop, it can be posited that fragile states are more likely to adopt this stance due to legitimacy and authority failures. Despite these challenges, CSOs must recognize that social services provision without confronting the root causes of poverty embedded in politics is not sustainable and has negative implications on development agendas nationally and globally. 


\section{Cathrine Madziva}

First, reluctance to engage in advocacy risks diminishing state accountability to the marginalized as CSOs can provide checks and balances on the state (Peruzzotti 2006). Secondly, the state risks formulating of ill-informed policies due to disengagement with those marginalized. Evidence suggests $\mathrm{CBO}$ s are more trusted by the marginalized than other institutions and are most likely to be cognizant of local needs than outsiders (Narayan et al., 2000). This places a burden of responsibility on CBOs to advocate on behalf of those they purport to represent. As Michael (2004: 155) argues:

"But within whatever field they choose to be active, local NGOs [and CBOs] must be ready to confront the underlying social and political forces that perpetuate underdevelopment ...[because] without confronting these political elements within development, local NGOs will never truly be able to change the lives of the poor and marginalised in their regions."

This is not a call for alignment with political parties, but seeking state accountability in line with sanctioned development mandates. On this note, the drive by CBO X's other donor for it to engage in political activities, such as 'fighting for democracy' an aspect not directly aligned to its development agenda appears misplaced. This potentially causes more harm than good by driving away organisations from advocacy due to the perceived limited connection between this and their sanctioned activities. While organizations can organically develop to 'fight for democracy', as a starting point, they should be supported to focus on political activities directly connected to their sanctioned development agendas. As argued elsewhere (Madziva 2017), INGOs are well placed to support CBO capacity building to engage in advocacy through partnerships given their expertise, which INGO T already does. However, this requires challenging the 'immediate concern' mind set, show casing the importance of advocacy and empowering communities to understand how their development agendas are connected to politics. The state's role in opening up the political space remains crucial. The historical cases of Bolivia, Colombia and Brazil show that states can open up political space for CSOs with positive outcomes in terms of influencing national policy agendas (World Bank 1997).

INGOs also face criticism for insufficient linkages with the poorest in the south, whom they purport to represent in relation to advocacy. This is on two fronts, i.e. inadequate funding allocations to advocacy (Anderson 2000) and limited participation by southern CSOs in international policy debates (Edwards 2000). This study however found the opposite as CBO $\mathrm{X}$ was under immense pressure from northern partners to engage in advocacy. It responded by taking cover under NANGO, whose integrity, at the time of study, was subject to criticism for having closer ties with the state and being at odds with its raison d'être 


\section{Cathrine Madziva}

(Michael 2004; Raftopolous 2000). Michael (2004) similarly highlights donors' uncharacteristic eagerness to fund advocacy in Zimbabwe while courting controversy and threats for it. This is attributed to the contentious relationship between the state and CSOs as follows:

"As the government, has sought to repress local NGOs working in the areas of lobbying and advocacy, donor confidence in the government has waned and donors have increased their support to NGOs. This has resulted in conflict, both over money and over political space" (Michael 2004: 65).

It could be further argued that donors largely blame the state for the prevailing socioeconomic and political crisis, hence supporting CSOs is an attempt to hold it accountable. However, the CSOs Michael (2004) identified as having incorporated advocacy in program activities appear urban based. Rural based CBOs contend with additional gate keepers, such as traditional leadership who are meant to be nonpartisan custodians of rural communities, but due to political polarization, are known to unleash violence to opposition party supporters at the behest of the ruling party (Baldwin and Muvengwa, 2014). On this note, context, whether urban or rural appears to impact on the nature and extent of advocacy engagement. Nonetheless, despite this incorporation, Michael (2004) argues that CSOs in Zimbabwe still lack opportunities to participate in higher-level policy decisionmaking due to the state's grip over political space.

While it has been argued that INGO linkages with CBOs and NGOs in the south can improve INGO legitimacy in global policy debates (Edwards 2000) the case of CBO X shows that linkages in fragile contexts may not be as productive. Though such linkages are a desirable starting point, state repression remains a major obstacle. The potential engagement of southern CSOs in advocacy at international levels while bypassing national and local levels potentially arms repressive states with propaganda thereby dismissing global led advocacy networks on country specific issues as northern agendas.

\section{Study Limitations}

This study is based on a partnership case study; hence these findings cannot be generalized (Bryman 2008). However, the contribution of an example to the accumulation of a relevant knowledge base remains crucial (Flyvbjerg 2004). This is because though methods designed to enable generalizations are extremely useful, they would not, on their own enable access to the complexities of a fragile context and implications on development activities. 


\section{Cathrine Madziva}

\section{Conclusion}

This paper aimed to explore the impact of contextual fragility on development in practice. Against a backdrop of Zimbabwe's past embedded in political violence, the study showed how an oppressive legislative framework limited communities participation which is crucial for sustainable development. The proposed NGO bill, though never signed to law, caused donors to jump ship leading to the collapse of some local organisations due to limited funding availability. Fearful of attracting state reproach, the $\mathrm{CBO}$ was reluctant to engage in advocacy activities deemed political despite donors' eagerness. As the most trusted institutions among the poor, $\mathrm{CBO}$ s have a greater burden of responsibility to confront the political forces which perpetuate their marginalization. Due to their expertise, INGOs are well placed to support rural $\mathrm{CBOs}$ in this endeavour through capacity development. Hyperinflation, bank closures and a pegged currency led to a partnership termination, partial and non-implementation of some intended development activities. Given these challenges, gaining a complete picture of fragility in each context should be a starting point for northern seeking to partner in such contexts. While the use of oppressive legislation and stringent registration to curb CSOs' engagement in political activities is a common thread among fragile and some none fragile states fearful of losing their political hegemony, the case of hyperinflation shows that, some factors are unique to specific fragile contexts. Hence, unmasking the heterogeneous nature of fragile contexts requires conducting contextual analysis for each context as this is likely to capture complexities and irregularities which may require extra considerations at program planning stages.

\section{References}

African Commission on Human and People's Rights, 2002 Fact-finding Mission to Zimbabwe Report. Banjul: African Commission on Human and People's Rights.

Amnesty International 2013. Annual Report: Zimbabwe 2013. Harare: Amnesty International Anderson, I. 2000 "Northern Advocacy: Perceptions, Reality and the Challenge". Development in Practice, 10 (3 \& 4): 445-452

Baldwin, K., and S. Muyengwa. 2014 Impact Evaluation of Supporting Traditional Leaders and Local Structures to Mitigate Community-Level Conflict in Zimbabwe. Harare: USAID.

Edwards, M. 2000 NGO Rights and Responsibilities: A New Deal for Global Governance. London: The Foreign Policy Centre and Voice of the Voluntary Sector

Fund for Peace 2017 Fragile Sate Index Annual Report. Washington DC: FFP

Foster, G. 2002 Understanding Community Response to the Situation of children affected by AIDS: Lessons for External Agencies. Geneva: UNRISD

Fournier, C. and Whittall, J. 2009 "When the affected state causes the crisis: the case of Zimbabwe". Policy Brief 43: 4-6

Fukuyama, F .2004 "State Building: Governance and World Order in the $21^{\text {st }}$ Century". New York: Cornwell University Press 
Hammersley, M., and Atkison, P 1995. "Ethnography: Principles in Practice". London: Routledge.

Harris, V. 2008. "Mediators or Partners? Practitioner Perspectives on Partnership." Development in Practice 18: 701-12.

Hayman, R. Lawo. T., Crack, R., Kontinen, T., Okitoi, J., Pratt, B. 2014 Legal Frameworks and Political Space for Non-Governmental Organisations: An overview of Six Countries, Phase 2. Bonn: Eadi

International Bar Association, 2004 An Analysis of the Zimbabwean NGO Bill. London: IBA International Centre for-Not- for Profit Law 2017 Zimbabwe. Washington DC: ICNL available at http://www.icnl.org/research/monitor/zimbabwe.html\#resources accessed 28 May 2017 International Centre for Not-for-Profit Law 2016 "Closing Civic Space: Impact on Development and Humanitarian CSOs." A Quarterly Review of NGO Legal Trends Around the World. 7 (3): $1-19$

Kagoro, B. 2005 "The Prisoners of Hope: Civil society and the opposition in Zimbabwe". African Security Review 14(3): 19-28

Kingsbury, D. 2014 "Challenges of Development in Difficult Sociopolitical Contexts". In Development in Difficult Socio-Political Contexts edited by A. Ware. Basingstoke: Palgrave Macmillan.

MacDonald, T. H. 2000 "Third World Health and it Dependence on First World Wealth". New York: The Edwin Mellen press

Madziva, C. 2017 "Community responses to Vulnerable Children in Rural Zimbabwe: Lessons from a Partnership Case Study". Development in Practice Journal 27(1):37-52

Makuwira, J. 2014 "Zimbabwe: Issues and Perspectives on Fragility and Failure". In Development in Difficult Socio-Political Contexts edited by A. Ware. Basingstoke: Palgrave Macmillan.

Mavinga, D 2016 Zimbabwe's Judges Under Fire Mugabe's Comments Undermine Judicial Independence. New York: Human Rights Watch

Mcloughlin, C. 2012 Topic Guide on Fragile States. Governance and Social Development

Centre. Birmingham: University of Birmingham

Michael, S. 2004 "The Absence of Power among Local NGOs in Africa". Oxford: James Currey Moyo, J. 1993 "Civil Society in Zimbabwe". Zambezi, 20(1) 1-13

Moyo, S. 2000 "The Structure and Characteristics of NGOs". In the State and Politics in Zimbabwe edited by S. Moyo, J. Makumbe, and B. Raftopoulos. Harare: SAPES

Muvingi, I.J. 2008 "The politics of Entitlement and State Failure in Zimbabwe" Peace Research 40 (1): 77-101

Narayan, D., Chambers, R. and Shah, M. K. 2000 "Voices of the Poor: Crying out for Change". Oxford: Oxford University Press

Peruzzotti, E. 2006 "Civil Society, Representation, and Accountability: Restating Current Debates on the Representativeness and Accountability of Civic Associations". In NGO Accountability: Politics, Principles and Innovations edited by L. Jordan, and P. Van Tujil. London: Earthscan

Prowse, M. and Bird, K. (2007) Economic contraction, markets and the chronically poor in Zimbabwe. Washington DC: USAID

Rafopoulos, B. 2000 "The state, NGOs and Democratisation". In The state and politics in Zimbabwe edited by S. Moyo, J. Makumbe, and B. Raftopoulos. Harare: SAPES

Ritchie, J., L. Spencer, and W. O'Connor. 2004 "Carrying out Qualitative Analysis." In Qualitative Research Practice: A Guide for Social Science Students and Researchers, edited by J. Ritchie, and J. Lewis. London: Sage

Rotberg, R.I. 2003 "Failed states, Collapsed States, Weak states". In State Failure and State weakness in a Time of Terror edited by R. I. Roterberg. Washington DC: The World Peace Centre. 
Safaids, 2012 Civil Society and People-Centered Development in Zimbabwe. Harare: Safaids Soros, G. 2008 "The new Paradigm for financial markets. The Credit Crisis of 2008 and what it means". Public Affairs: New York.

Stewart F. and Brown, G. 2009 Fragile States. CRISE Working Paper 51. Oxford: CRISE

The Economist, 2016. Zimbabwe's begging bowl: Bailing out bandits. The Economist, 9 July The Economist, 2005 Cleaning up in Zimbabwe. The Economist, 9 June

The Economist, 2017 Zimbabwe's "bond notes": The King of Funny Money. The Economist, 18 February

UNAIDS, 2016 Global AIDS Response Progress Report 2016: Zimbabwe Country Report. Geneva: UNAIDS

USAID, 2008 Health System Fact Sheet: Zimbabwe. Washington DC: USAID

Ware, A. 2014 "Beyond the Usual Suspects: Complexity of Fragile and Analytical

Framework". In Development in Difficult Socio-Political Contexts edited by A. Ware.

Basingstoke: Palgrave Macmillan.

World Bank 2002 Ensuring Good Governance in Poverty Reduction. Washington DC: World Bank

World Bank, 1997 Handbook on Good Practices for Laws Relating to Non-Governmental Organisations. Washington DC: World Bank

Zimbabwe Peace Project, 2015 International Human Rights Day Statement. Harare:

Zimbabwe Peace Project 